\title{
An Overview of Food Emulsions: Description, Classification and Recent Potential Applications
}

\author{
Meltem Serdaroğlu ${ }^{1}$, Burcu Öztürk ${ }^{1 *}$, Ayşe Kara ${ }^{2}$ \\ ${ }^{1}$ Ege University, Engineering Faculty, Food Engineering Department, 35100, Bornova/İmir, Turkey \\ ${ }^{2}$ Defne Spices Co., 35730 Kemalpaşa/İzmir, Turkey
}

A R T I C LE INFO

Article history:

Received 15 February 2015

Accepted 17 March 2015

Available online, ISSN: 2148-127X

Keywords:

Emulsion

Emulsification

Food emulsions

Nanoemulsion

Double emulsion

Emulsifying agent

${ }^{*}$ Corresponding Author:

E-mail: burcu.ozturk@ege.edu.tr
A B S T R A C T

Emulsions take place partially or completely in the structures of many natural and processed foods or some foods are already emulsified in certain stages of production. In general "emulsion" is described as a structure created through the dispersion of one of two immiscible liquids within the other one in form of little droplets. Many terms are available to describe different emulsion types and it is very important to define and clarify these terms like "macro emulsion", "nanoemulsion" and "multiple emulsion". Nanoemulsions become increasingly important in food industry as an innovative approach in carrying functional agents. Application potential of multiple emulsions $(\mathrm{W} / \mathrm{O} / \mathrm{W})$ is also stated to be very high in food industry. The two main strategic purposes of utilization of multiple emulsions in food applications are to encapsulate various aromas, bioactive compounds or sensitive food compounds and to allow the production of the low-fat products. This review provides an overview to the general terms of emulsion types, the role of various emulsifying agents, and the application potential of emulsions in food industry.

\section{Introduction}

Emulsion science is a multi-disciplinary subject covering chemistry, physics and engineering. The purpose of emulsion science in food industry is to develop food quality and production techniques by benefiting from emulsion principles. Emulsions take place partially or completely in the structures of many natural and processed foods or some foods are already emulsified in certain stages of production (McClements, 2005). Foods like milk, cream, butter, margarine, juice, soup, cake, pastry, mayonnaise, cream liqueur, coffee creamer, sauce and ice cream may be shown as examples to emulsiontype products (Dickinson and Stainsby, 1982; Krog et al., 1983; Dickinson, 1992; Swaisgood, 1996; Friberg and Larsson, 1997; Charcosset, 2009). Furthermore, many meat products depend on the presence of emulsions for their properties, as does bread dough, although in both cases the emulsion structures can be extremely complex (Dalgleish, 2004). Emulsion based food products have important differences in terms of physicochemical and organoleptic characteristics like appearance, flavour, texture, taste and shelf life. For example, milk is a white fluid with low viscosity, strawberry yogurt is a pink viscoelastic gel and margarine is a yellow semi-solid. Production of an emulsion based food product having specific quality characteristics depends considerably on the selection of most appropriate raw materials (for example; water, oil, emulsifying agent, thickening agent, minerals, acids, bases, vitamins, aromas, colorants, etc.) and process conditions (for example; mixture, homogenization, pasteurization, sterilization, etc.) (McClements, 2005).

In general "emulsion" is described as a structure created through the dispersion of one of two immiscible liquids within the other one in form of little droplets (generally oil and water) (Dickinson,1992; McClements, 2005; McClements et al., 2007; Zhang, 2011). Emulsions may be divided conventionally into two as water-in-oil emulsions (W/O) and oil-in-water $(\mathrm{O} / \mathrm{W})$ emulsions in accordance with their continuous and disperse phases. Many of food emulsions consist of three main zones with different physicochemical characteristics: "disperse phase" generating droplets, "continuous phase" surrounding droplets and interface (McClements, 2005; McClements et al., 2007). Emulsion molecules are distributed within these phases in accordance with their concentrations and polarities (Wedzicha, 1988). Nonpolar and polar molecules tend to be located in the oil phase and water phase, respectively, while the amphiphilic molecules tend to be located onto interface (McClements, 2005). Some examples for phase distribution of different emulsions by transmission electron micrographs could be seen in Figure 1. 

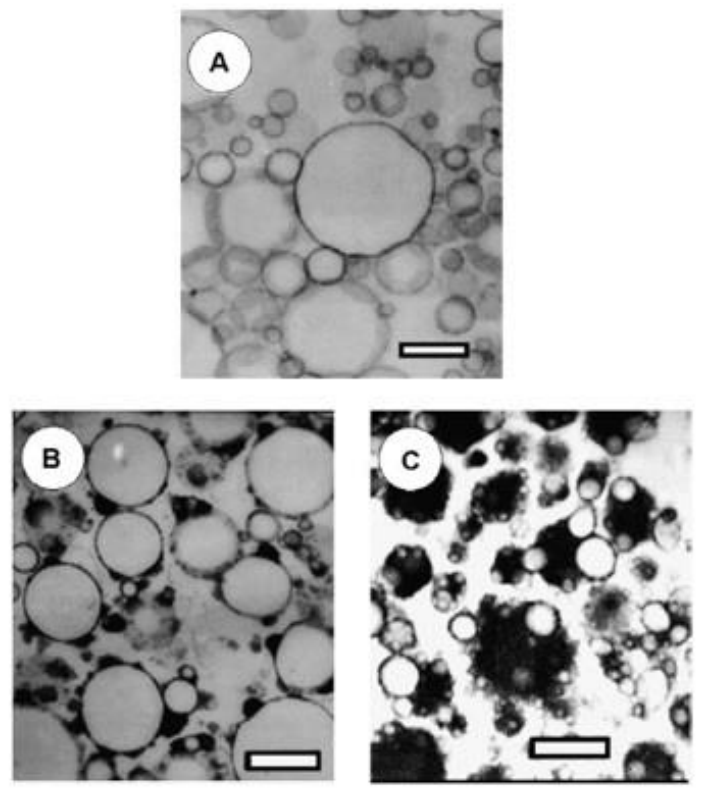

Figure 1 Transmission electron micrographs of different emulsions. (a) an emulsion of soya oil stabilized by sodium caseinate, showing the surface covered by protein layer. (b) fat globules from a sample of homogenized milk, showing casein micellar material (dark clumps) on the interface. (c) smaller particles from homogenized milk, showing high protein load. Scale bar in A and B represents $300 \mathrm{~nm}$, and in C $200 \mathrm{~nm}$ (Dalgleish, 2006).

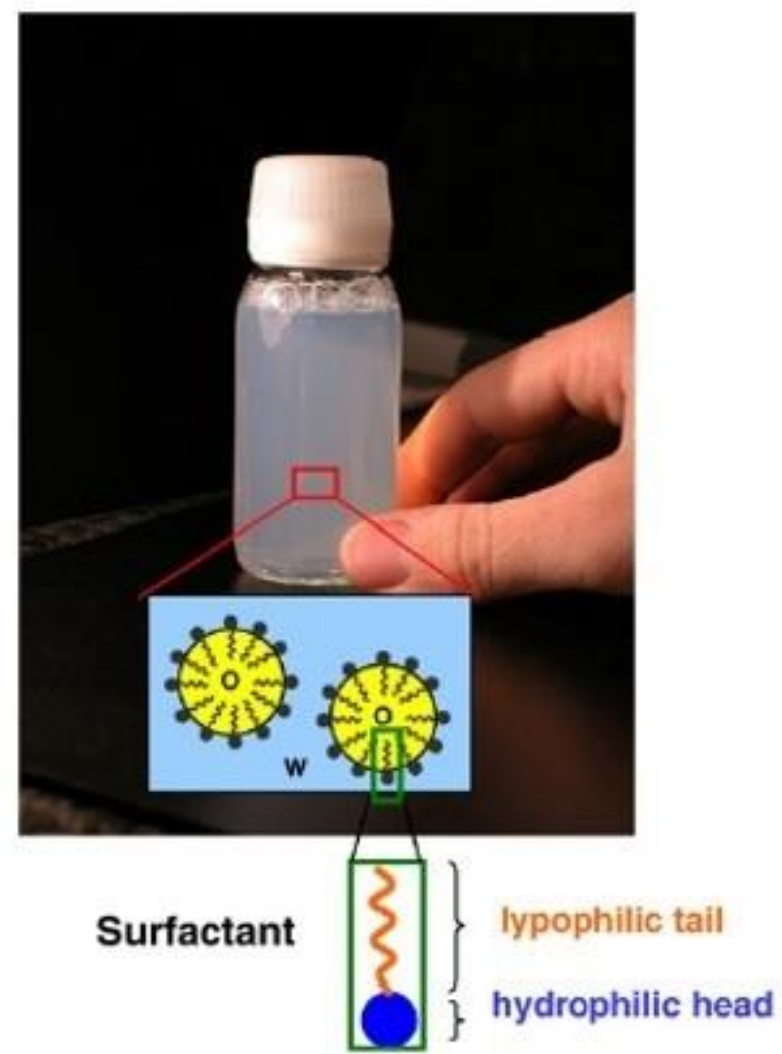

Figure 2 Visual aspect of an $\mathrm{O} / \mathrm{W}$ nanoemulsion and structural conformation of the droplets (Gutiérrez et al., 2008).
Food emulsions are complex materials in terms of composition. Composition of an emulsion can be determined considering various aspects like concentration of specific atoms $(\mathrm{H}, \mathrm{C}, \mathrm{O}, \mathrm{N}, \mathrm{Na}$, etc.), molecules (water, sucrose, amylase, $\beta$-lactoglobulin, etc.), molecule groups (proteins, lipids, carbohydrates, minerals, etc.) and components (flour, milk, salt, egg, etc.) (McClements, 1999). The water phase of a food emulsion plays a significant role in determining physiochemical and organoleptic features. The unique molecular and structural characteristics of water enhance many important functions such as providing dissolving medium and interaction with many water-soluble components (mineral, acid, base, aroma, preservative, vitamin, sugar, emulsifying agent, protein, polysaccharide, etc.) (Dickinson, 1992; McClements, 1999). Oil phase is another important component since it possesses aroma components in oil-water interface and acts as a solvent for various ingredients, including oil-soluble vitamins, antioxidants, preservatives and essential oils (McClements, 1999). For determining the characteristic features of food emulsions, it is important to make a comprehensive evaluation of emulsification procedures, emulsion phases, droplet behaviours and emulsifying agent functions. Within this review, it was targeted to summarize the types and roles of emulsions and emulsifying agents used in potential food applications.

\section{Emulsions-Classification and Potential Applications in Food Systems}

\section{Macro and micro emulsions}

Since many terms are available to describe different emulsion types, it is of great importance to clarify these definitions. Some characteristic features of different emulsion types are stated in Table 1. Droplet size (or diameter) is one of the most characteristic features of an emulsion for classification, where in every emulsion the droplet size is shaped randomly. The size of the droplets is mostly effective to determine the formation of physical and thermodynamic properties. Typical droplet diameters of conventional emulsions, called as "macroemulsions", range between $100 \mathrm{~nm}$ and $100 \mu \mathrm{m}$. Macroemulsions constitute the most common emulsion type used in many different forms like milk, beverages, coatings, mayonnaise, dipping sauces, sauces and deserts. Macro emulsions tend to be physically instable especially when they undergo environmental stress (eg. gravitational separation, aggregation, coagulation, Ostwald ripening) (Aoki et al., 2005; McClements et al., 2007; Dickinson, 2009; Peter, 2009; Zhang, 2011).

Microemulsions are thermodynamically stable and spontaneously shaped in diameters ranging from 5 to 100 nm (Flanagan and Singh, 2006; Zhang, 2011). In general, researchers consider that nanoemulsions are similar to microemulsions since both of them include typically water, oil and surface-active components and have also similar droplet size. However, nanoemulsions are formed by mechanical force, while microemulsion phases are 
Table 1 Some thermodynamic and physicochemical properties of colloidal dispersions formed with oil, water an emulsifying agents*

\begin{tabular}{l|cccc}
\hline System & Droplet Diameter & $\begin{array}{c}\text { Thermodynamic } \\
\text { Stability }\end{array}$ & $\begin{array}{c}\text { Surface-mass ratio } \\
\left(\mathrm{m}^{2} / \mathrm{g} \text { particle }\right)\end{array}$ & Optical properties** \\
\hline Macroemulsion & $100 \mathrm{~nm}-100 \mu \mathrm{m}$ & Instable & $0.07-70$ & Opaque/Turbite \\
Nanoemulsion & $20-200 \mathrm{~nm}$ & Instable & $70-330$ & Lucent/Turbite \\
Microemulsion & $5-100 \mathrm{~nm}$ & Stabile & $330-1300$ & Lucent/Turbite \\
\hline
\end{tabular}

*(Solans et al., 2005; Flanagan and Singh, 2006; McClements and Rao, 2011; Zhang, 2011)., ** The optical properties have been expressed according

to significant refractive index values in significant particle concentrations depending on typical oil-water systems.

formed by self-assembly. In other words, a mixture including appropriate amounts of water, oil and surfaceactive components may naturally generate a microemulsion (Moulik and Paul, 1998; Fanun, 2009; Zhang, 2011). Therefore, the main difference between microemulsions and micro-size emulsions arise from thermodynamic characteristics of emulsion rather than composition (Flanagan and Singh, 2006; Whitesides and Grzybowski, 2002; Zhang, 2011).

\section{Nanoemulsions}

Nanoemulsions are defined as the structures having typically 20-200 $\mathrm{nm}$ droplet diameters (Solans et al., 2005). Nanoemulsion term has been first used by Nakajima et al. (1993) and called by different terms like "miniemulsion" (El-Aasser and Sudol, 2004), "submicron emulsion" (Amselem and Friedman, 1998) or "ultrafine emulsion" (Nakajima, 1997) until today. It is recommended by Solans et al. (2005) to use the term "nanoemulsion" among the other terms, since it clearly describes that droplets are at nano-level and it differs completely from the term of microemulsion. Nanoemulsions are superior to conventional emulsions since they have a transparent and semi-translucent appearance (See Figure 2), smaller droplet size, they are stable against sedimentation and creaming and they tend to increase bioavailability (Shakeel et al., 2008; Wang et al., 2008; Zhang, 2011; Solans and Solé, 2012). In addition to their high colloidal stability, nanoemulsions need less than $10 \%$ surface-active agent in preparation stages (while this rate is $20 \%$ or higher in microemulsions). Furthermore, since nanoemulsions provide a wide surface area, they lead active components to be penetrated quickly (Laouini et al., 2012). Contrary to thermodynamically stable microemulsions, nanoemulsions are unstable systems which might be exposed to environmental degradation (Solans and Solé, 2012). The formation and manufacturing control of nanoemulsions require high shear force application in order to cope with surface tension of droplets (Mason et al., 2006). Since nanoemulsions are non-equilibrium systems, they could not be formed spontaneously and typically energy input of a mechanical device is required (Zhang, 2011). Thus, in general high-energy methods are used for preparation of nanoemulsions (high pressure homogenizers (Solans et al., 2005; Sanguansri and Augustin, 2006; Zhang, 2011), microfluidizers (Swientek, 1990; Dalgleish et al., 1997; Guraya and James, 2002; Kwon et al., 2002; Thompson and Singh, 2006; Jafari et al. 2006, 2007) and ultrasonic generators (Xia et al., 2001;
Sanguansri and Augustin, 2006; Kentish et al., 2008; Li and Chiang, 2012; Chandrapala et al., 2012; Ghosh et al., 2013). There have been also a number of studies applying low-energy methods for production of nanoemulsions, by using the chemical potential of the components under special conditions (Acosta, 2009; Rao and McClements, 2010; Calderó, et al., 2011; Solans and Solé, 2012).

Nanoemulsions become increasingly important in food industry as an innovative approach in carrying functional agents like fatty acids, polyphenols, vitamins, natural colorants, antimicrobials, some micronutrients and flavours (Seikikawa and Watanabe, 2008; Mao et al., 2009; McClements and Rao, 2011; Rao et al., 2011; Zhang, 2011; Laouini et al., 2012). In general oil-in-water (O/W) nanoemulsions have started to be investigated for a while ago and their role in such polymerization reactions as nanoreactors has been searched (Solans et al., 2005). In previous studies, $\mathrm{O} / \mathrm{W}$ nanoemulsion systems have been used as a carrier and combiner in food in order to encapsulate $\mathrm{w}-3$ fatty acids in yoghurt (Chee et al., 2005) and ice cream (Chee et al., 2007). Compared to O/W nanoemulsions, water-in-oil $(\mathrm{W} / \mathrm{O})$ nanoemulsions are the types which have started to be examined recently and have a more limited study area (Solans et al., 2005). Therefore, it could be concluded that $\mathrm{O} / \mathrm{W}$ nanoemulsions offer a good potential in food applications especially for encapsulation purposes. It is necessary to understand basic physicochemical characteristics of food nanoemulsions in order to provide key-information to increase the applicability of nanoemulsion in foods and to guide better formulations (Zhang, 2011).

\section{Multiple emulsions (multiplex/double/multilayered emulsions)}

A multiple emulsion is described as "emulsion of an emulsion" (Benichou et al., 2004, 2007; Muschiolik, 2007; Dickinson, 2011). In multiple emulsions, an emulsion structure is formed, where water-in-oil (W/O) and oil-in-water $(\mathrm{O} / \mathrm{W})$ morphologies exist together. Multiple emulsions have two main types as water-in-oilin-water (W/O/W) and oil-in-water-in-oil (O/W/O) (Dickinson, 2011). In a conventional single layer emulsion there are only two mass phases and one oilwater interface. However, in a multiple emulsion there are three different mass phases and two oil-water interface. In a $\mathrm{W}_{1} / \mathrm{O} / \mathrm{W}_{2}$ type emulsion, $\mathrm{W}_{1}$ and $\mathrm{W}_{2}$ constitute internal water phase and external water phase, respectively. In such type of emulsion there are two different interface layers: $\mathrm{W}_{1}-\mathrm{O}$ layer surrounds internal water droplets and $\mathrm{O}-\mathrm{W}_{2}$ layer surrounds oil droplets (McClements et al., 
2007). Since there are two types of interfaces in multiple emulsions, typically two different emulsifying agents (EA) should be incorporated in the structure. The first one is used to stabilize internal droplets (primary emulsion) and the second one is used to stabilize external droplets (secondary emulsion) (de Cindio et al., 1991; Dickinson, 2011). Evaluating the solubility characteristics, a fatsoluble EA and a water-soluble EA are needed to stabilize internal water droplets and oil droplets, respectively (McClements et al., 2007).

Multiple emulsions are very complex and thermodynamically unstable dispersion systems which tend to flocculate, aggregate and creaming in practice (Benichou et al., 2007; Charcosset, 2009). Due to osmotic pressure gradient, water transition is seen from one aqueous phase to another through oily membrane; in this situation when the internal phase has lower osmotic pressure than the external phase, shrinkage occurs in the inner droplets. Conversely, when the internal phase has a higher osmotic pressure than the external phase, swelling occurs in the inner droplets (Dickinson, 2011). Therefore, it should be targeted to form stable emulsions benefiting from appropriate equipment and emulsifying agents. Muschiolik (2007) stated that depending on the emulsification method and the emulsion composition, multiple food emulsions can be stable for a long time.

In preparation of $\mathrm{W}_{1} / \mathrm{O} / \mathrm{W}_{2}$ emulsions, a standard twostep method is used: in the first step, water, oil and EA are homogenized using a lipophilic emulsifying agent (EA) to prepare a $\mathrm{W}_{1} / \mathrm{O}$ emulsion. In the second step, using a hydrophilic EA, EA and $\mathrm{W}_{1} / \mathrm{O}$ emulsion are added to aqueous solution and homogenized to form $\mathrm{W}_{1} / \mathrm{O} / \mathrm{W}_{2}$ emulsion (see Figure 3) (McClements et al., 2007; Dickinson, 2011). The main molecular and colloidal factors affecting the coalescence stability of the inner and outer droplets are essentially the same as those for simple $\mathrm{W} / \mathrm{O}$ and $\mathrm{O} / \mathrm{W}$ emulsions, respectively. But complexity in $\mathrm{W} / \mathrm{O} / \mathrm{W}$ emulsions arises from the tendency of emulsifiers with different hydrophilic-lipophilic balance to have destabilization effect on each other. Ideally, lipophilic emulsifier is expected to be positioned completely in water-oil interface. However, in practice lipophilic emulsifier should be present at higher amounts in the oil phase in order to make the primary emulsion droplets sufficiently small. In this way solubility and mass transfer of water-soluble compounds through the oily membrane increase at higher rate, but since a part of remaining lipophilic emulsifier transports into water-oil interface, it affects the stabilization mechanism of secondary hydrophilic emulsifier negatively (Dickinson, 2011). Apart from this, it was reported that both oil molecules themselves and active materials tend to diffuse from internal phase to external phase due to osmotic pressure difference (Benichou et al., 2004, 2007). Therefore, adjustment of stability balances in primary and secondary emulsions is of great importance in formation of multiple emulsions.

Multiple emulsions are used extensively in the encapsulation of active components in medicine, pharmacy, cosmetics and biomedical sciences
(Charcosset, 2009; Dickinson, 2011). Application potential of multiple emulsions is stated to be very high in food industry (O'Regan and Mulvihill, 2010). O/W/O emulsions constitute the emulsion type which is made up of disperse phase where oil droplets are confined by water and the continuous phase is oil (Dickinson, 2011). Even though $\mathrm{O} / \mathrm{W} / \mathrm{O}$ emulsions have been studied in a number of researches in food, cosmetics and pharmacy, they are mentioned as the least preferred emulsion systems in food applications (Benichou et al., 2007). W/O/W emulsions are formed in a way that small water droplets covered by greater oil droplets are dispersed in a continuous water phase (McClements et al., 2007; O'Regan and Mulvihill, 2010; Dickinson, 2011). Multiple emulsions are generally used in food industry applications in W/O/W form, since many food emulsions including a continuous aqueous phase and a dispersed oil phase could be stabilized by selecting hydrophilic food-grade emulsifying agents (O'Regan and Mulvihill, 2010). Therefore, multiple emulsion term in foods may be used directly as "W/O/W emulsion".

Utilization of $\mathrm{W} / \mathrm{O} / \mathrm{W}$ emulsions in food applications is based on two main strategic purposes: First purpose is to encapsulate various aromas, bioactive compounds or sensitive food compounds (in this way such compounds may be kept at a controlled level during consumption and digestion) (de Cindio et al., 1991; Garti, 1997; McClements et al., 2007; Choi et al., 2009; McClements et al., 2009; Dickinson, 2011). By this way, W/O/W emulsions have been stated to be a useful strategy in masking off-flavours and controlling the release and protection of labile ingredients (Bou et al., 2013). Since multiple emulsions offer the opportunity to enclose nutritional and bioactive compounds, and these emulsions could be used as food ingredients, they offer an interesting approach among the technological strategies used to optimize dietary active components in new food systems such as functional foods (Jiménez-Colmenero, 2013). Thus the second strategy of $\mathrm{W} / \mathrm{O} / \mathrm{W}$ emulsion applications is to allow the production of the products which are healthier and low-fat (de Cindio et al., 1991; Garti, 1997; McClements et al., 2007; Choi et al., 2009; Dickinson, 2011; Bou et al., 2013; Serdaroğlu et al., 2013a). As known, in recent years low-fat products are demanded increasingly by reasons of consumers' consciousness level on foodstuffs, change in their expectations, their tendency towards healthier products and tendency to decrease various disease risks. Therefore, $\mathrm{W} / \mathrm{O} / \mathrm{W}$ emulsions constitute an innovative approach in low-fat food production. The concept here is to lower the oil content of a conventional $\mathrm{O} / \mathrm{W}$ emulsion by replacing it with an equivalent $\mathrm{W} / \mathrm{O} / \mathrm{W}$ emulsion of similar perceived fat content (Dickinson, 2011). As reported by Jiménez-Colmenero (2013), it should be possible to produce reduced-fat products with similar physicochemical and sensory properties as full-fat products. W/O/W emulsions are stated also to have other favorable effects like developing taste (de Cindio et al., 1991) and preventing oxidation (Choi et al, 2009; O’Regan and Mulvihill, 2010; Serdaroğlu et al., 2014) 
since it includes water in external (i.e. continuous) phase. There have been patented studies on the use of $\mathrm{W} / \mathrm{O} / \mathrm{W}$ emulsions in salty creams (salt-encapsulated) and aromatic mayonnaises (flavour-encapsulated) (de Cindio et al., 1991; Garti, 1997). Márquez and Wagner (2010) reported that a double emulsion can work as a reduced-fat substitute for whipped dairy cream. Lobato-Calleros et al. (2006, 2008) carried out studies about low-fat (decreased oil content up to $26 \%$ ) white cheese production by using W/O/W emulsions including canola oil stabilized with some hydrocolloids without causing considerable difference in sensorial, textural and rheological properties as compared with control groups. In a similar research, oil-reduced (decreased to $13.2 \%$ ) Mozarella cheese was produced by utilization of $\mathrm{W} / \mathrm{O} / \mathrm{W}$ emulsions formed with corn oil and hydrocolloids where the samples with W/O/W emulsions were featured to be harder and stickier to be resistant to external force, with developed cross-link structure and tensibility of proteins compared with control groups (Xu et al., 2011). The results of a study about lowfat yoghurt production showed that in $\mathrm{W} / \mathrm{O} / \mathrm{W}$ emulsion groups formed by using canola oil and carboxymethylcellulose (CMC) or pectin, the oil content was decreased up to $0.56 \%$ in $\mathrm{CMC}$ and $0.52 \%$ in pectin groups, in comparison with the oil content of $2.95 \%$ in control group (Lobato-Calleros et al., 2009). In a study targeted to characterize multiple emulsions and evaluated their utility as pork backfat replacers in meat gel/emulsion model systems, the W/O/W emulsions prepared with olive oil, PGPR (polyglycerol polyricinoleate), sodium caseinate and whey protein concentrate showed a welldefined monomodal distribution, good thermal stability with no creaming and the meat systems had good water and fat binding properties irrespective of formulation (Cofrades et al., 2013). Bou et al. (2013) stated that it could be possible to produce a W/O/W emulsion as a lowfat food ingredient for the meat industry that is stable to environmental stresses typically occurring in the food industry. Serdaroğlu et al. (2014) reported improved quality characteristics in model system meat emulsions manufactured with W/O/W emulsions containing olive oil, PGPR, sodium caseinate or egg white powder, in terms of emulsion stability, oxidation and storage, meanwhile $\mathrm{W} / \mathrm{O} / \mathrm{W}$ emulsions were suggested to have a good potential to be used in meat emulsions as animal fat replacers and to allow production of low-fat and fatty acid composition modified meat products. According to these data, it could be concluded that utilization of $\mathrm{W} / \mathrm{O} / \mathrm{W}$ emulsions offers a considerable opportunity in low-fat food production, without causing quality defects in the structure of products.

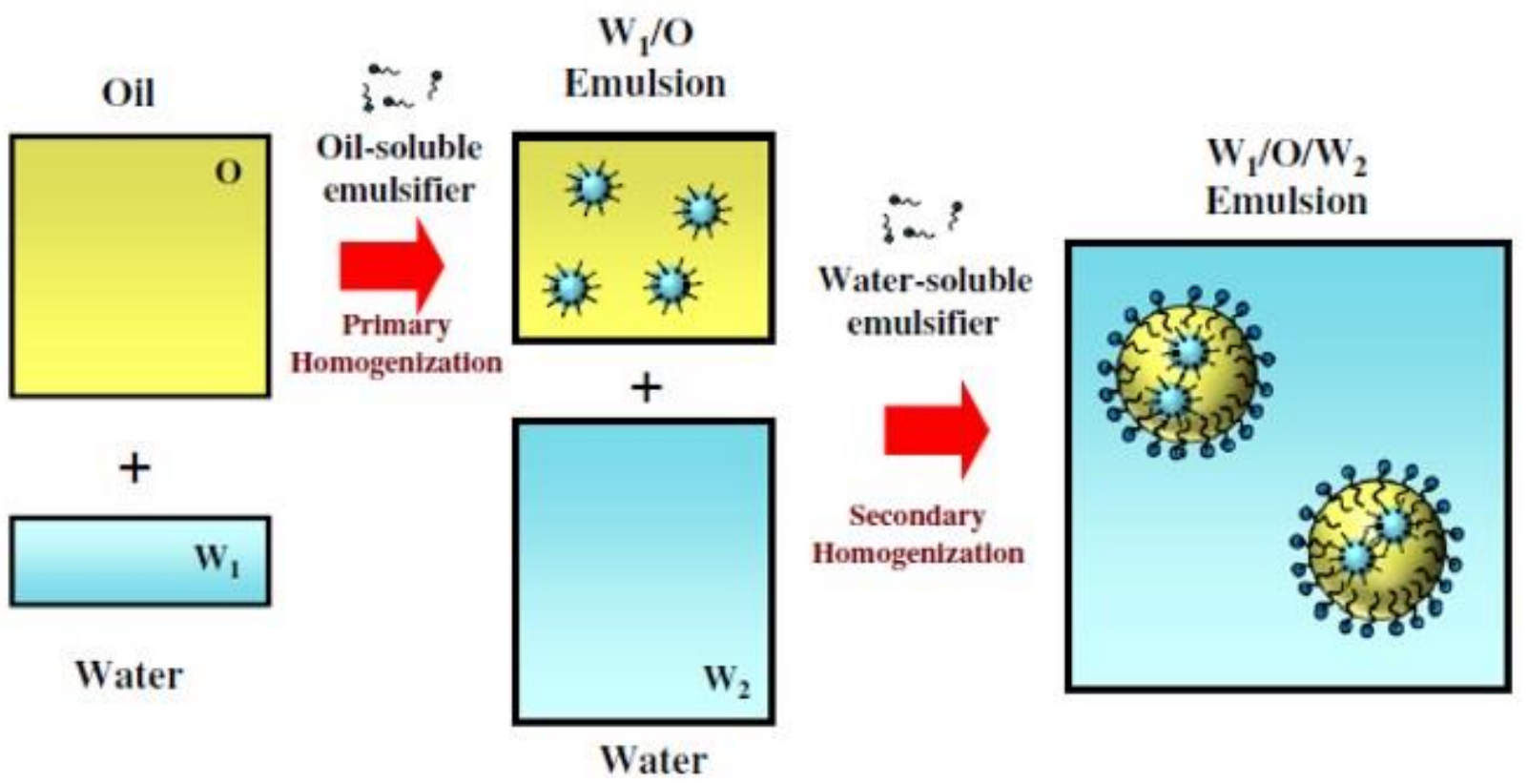

Figure 3 Multiple emulsions (W/O/W) are usually produced using a two-step procedure: (i) primary homogenization: an oil and an aqueous phase are homogenized together in the presence of an oil-soluble emulsifier to form a W/O emulsion; (ii) secondary homogenization: the W/O emulsion is homogenized with a water phase in the presence of a water-soluble emulsifier to form a W/O/W emulsion. Homogenization may be carried out using a variety of devices (McClements, 2012). 


\section{Emulsifying Agents}

Emulsifying agents (EAs) are very important ingredients having an essential role to ensure emulsification and stability in the formation of emulsions in aqueous solutions (Krog and Sparso, 2004; McClements, 2005). EAs are amphiphilic molecules including both hydrophilic and lipophilic parts (Zhang, 2011). EAs are surface-active compounds being absorbed on the surface of droplets and ensuring kinetic stability in a certain period by being added into emulsion before or after homogenization (McClements, 1999; McClements et al, 2007). Components like thickening agents and stabilizing agents used in the formation of emulsions are different and shouldn't be confused with the term of emulsifying agent. Thickening agents typically increase the viscosity in the continuous phase of emulsion and limit the movements of droplets and develop emulsion stability in this way. Stabilizing agents are used to increase the stability provided by both emulsifying agents and thickening agents (McClements, 1999).

The principal effects of emulsifying agents could be listed as follows:

- To decrease the interface tension between wateroil phase or water-air phase and to create an interface membrane by providing structural or electrostatic interactions between droplets,

- To decrease the required amount of energy for the degradation of coarse particles and thus to ensure the formation of smaller droplets,

- To prevent coalescence by creating a protective layer surrounding droplets,

- To provide additional functions like modifying oil crystallization, making interactions with carbohydrate components, forming films and controlling the transport of oxygen or moisture (Krog and Sparso, 2004; McClements, 1999; McClements, 2005; Zhang, 2011)

A number of food components exhibiting the mentioned characteristics (e.g. lecithin, proteins, gums, modified starches, phospholipids, etc.) could be used as EAs. However, these components vary considerably in terms of their molecular structure, which influences their ability to form and stabilize emulsions, as well as withstand environmental stress, such as variations in ionic strength, $\mathrm{pH}$ and temperature (Zhang, 2011). One of the common problems encountered by researchers is to form stable multiple emulsions with food-grade EAs instead of synthetic surface-active components and polymers. In order to ensure stability in non-food emulsion products, utilizing sorbitan esters and synthetic co-polymers is a common and simple method. In order to develop emulsion applications in food, researchers mainly focus on the usage of food proteins and polysaccharides (Kanouni et al., 2002; Benichou et al., 2007; Dickinson, 2011). In conventional emulsions having the opportunity to be used as fat-replacers in meat, some food-grade ingredients have been utilized to improve stability and functional properties (Delgado-Pando et al., 2010: sodium caseinate, soy protein isolate or microbial transglutaminase in O/W; Serdaroğlu et al., 2013b: egg white powder in O/W; Kara et al., 2013: carrot powder in W/O; Urgu et al., 2013: hazelnut powder in O/W). Delgado-Pando et al. (2010) stated that non-meat proteins improve the system's fat binding ability, since the oils can be stabilized or immobilized in a protein matrix.

In order to stabilize primary emulsion in $\mathrm{W} / \mathrm{O} / \mathrm{W}$ food emulsions, in other words to stabilize the droplets in internal phase, there have been several studies where various biopolymers like gelatin (Evison et al., 1995; Vaziri and Warburton, 1994; Fechner et al., 2007; Hemar et al., 2010; O'Regan and Mulvihill, 2010; Sapei et al., 2012), caseinate (Su et al., 2006), whey protein (Knoth et al., 2005; Kim et al., 2006; Hemar et al., 2010), bean protein (Koberstein-Hajda and Dickinson, 1996), gum acacia (Vaziri and Warburton, 1994; Su et al., 2008), xanthan gum (Evison et al., 1995), gelled starch (Iancu et al., 2009) have been utilized. PGPR is known as a synthetic and strongly lipophilic emulsifier widely used to stabilize both W/O and W/O/W emulsions (Scherze et al., 2007; Su, 2008; Lutz et al., 2009; O'Regan and Mulvihill, 2010; Pawlik et al., 2010; Xu et al., 2011; Zhang, 2011; Sapei et al., 2012; Öztürk et al., 2014). The use of additional emulsifiers, like sodium caseinate has been suggested as a strategy to reduce the amount of PGPR (Gülseren and Corredig, 2014). Providing a synergistic effect by using these emulsifiers, it is possible to decrease total PGPR content up to 75\% (Su et al., 2006; Dickinson, 2011). Colloidal particles of many polysaccharides such as carrageenan, locust bean gum (Suzuki and Lim, 1994; Benna-Zayani et al., 2008; Perrechil and Cunha, 2012), xanthan gum (Benna-Zayani et al., 2008), pectin (Kim et al., 2006; Lobato-Calleros et al., 2008; Murillo-Martínez et al., 2011; Xu et al., 2011), gum arabic (Lobato-Calleros et al., 2008; Xu et al., 2011), whey protein isolate (Murillo-Martínez et al., 2011), sodium caseinate (FraschMelnik et al., 2010; Perrechil and Cunha, 2012; Öztürk et al., 2014; Serdaroğlu et al., 2014), egg white powder (Öztürk et al., 2014; Serdaroğlu et al., 2014) and microcrystalline cellulose (Oza and Frank, 1989; Kim et al., 2005) have been utilized serving as thickening/gelling agents in stabilizing the droplets of secondary emulsions, i.e. external phase of multiple emulsions. It could be possible to ensure optimum stability by selecting and using appropriate proteins and polysaccharides together in primary and secondary emulsions to obtain a synergistic effect. Since the convenience of EAs used, the formulation and composition of the emulsion and the emulsification methods are main effective factors on stability issues, by taking all of these points into account, it could be possible to obtain acceptable emulsions protecting their structural stability for a desired time.

\section{Conclusion}

In recent years, conventional or multiple emulsions produced in different scales (macro or nano sizes) have been drawing ever-increasing interest in food industry due to their innovative usage area. Nano-sized emulsions have 
a great potential since they allow to carry functional and sensitive agents in food. Multiple emulsions offer good alternatives in encapsulating various aromas, bioactive or sensitive food compounds and promotes the production of low-fat and healthier products. It seems possible to improve many desired quality characteristics by benefiting from potentials of emulsions in food. For this purpose, it becomes important to better understand the biochemical mechanism of the formation and stability issues of emulsions, the role and combined effects of emulsifying agents and to determine most appropriate methods in preparing emulsions.

\section{References}

Acosta E. 2009. Bioavailability of nanoparticles in nutrient and nutraceutical delivery. Current Opinion in Colloid and Interface Science, 14: 3-15. DOI: 10.1016/j.cocis.2008.01.002

Amselem S, Friedman D. 1998. Submicron emulsions as drug carriers for topical administration. In: Benita S. Submicron Emulsions in Drug Targeting and Delivery. $9^{\text {th }}$ Edition. London: Harwood Academic Publishers. pp: 153-173. ISBN: 9057023490, 9789057023491

Aoki T, Decker EA, McClements DJ. 2005. Influence of environmental stresses on stability of $\mathrm{O} / \mathrm{W}$ emulsions containing droplets stabilized by multilayered membranes produced by a layer-by-layer electrostatic deposition technique. Food Hydrocoll, 19: 209-220. DOI:10.1016/j.foodhyd. 2004.05.006

Benichou A, Aserin A, Garti N. 2004. Double emulsions stabilized with hybrids of natural polymers for entrapment and slow release of active matters. Advances in Colloid and Interface Science, 108-109: 29-41. DOI: 10.1016/j.cis.2003.10.013

Benichou A, Aserin A, Garti N. 2007. O/W/O double emulsions stabilized with WPI-polysaccharide conjugates. Colloids and Surfaces A: Physicochemical and Engineering Aspects, 297 211-220. DOI: 10.1016/j.colsurfa.2006.10.048

Benna-Zayani M, Kbir-Ariguib N, Trabelsi-Ayadi M, Grossiord J. 2008. Stabilisation of W/O/W double emulsion by polysaccharides as weak gels. Colloids and Surfaces A: Physicochemical and Engineering Aspects, 316: 46-54. DOI: 10.1016/j.colsurfa.2007.08.019

Bou R, Cofrades S, Jiménez-Colmenero F. 2013. Properties of $\mathrm{W}_{1} / \mathrm{O} / \mathrm{W}_{2}$ emulsions as potential fat replacers in meat products. In: Serdaroğlu M, Öztürk B, Akcan T. 59 ${ }^{\text {th }}$ ICOMSTInternational Congress of Meat Science and Technology, 18-23 August, 2013, Izmir, Turkey.

Calderó G, García-Celma MJ, Solans C. 2011. Formation of polymeric nano-emulsions by a low-energymethod and their use for nanoparticle preparation. Journal of Colloid and Interface Science, 353: 406-411. DOI: 10.1016/j.jcis.2010.09.073

Chandrapala J, Oliver C, Kentish S, Ashokkumar M. 2012. Ultrasonics in food processing. Ultrasonics Sonochemistry, 19: 975-983. DOI:10.1016/j.ultsonch.2012.01.010

Charcosset C. 2009. Preparation of emulsions and particles by membrane emulsification for the food processing industry. $\mathrm{J}$ Food Eng, 92: 241-249. DOI: 10.1016/j.jfoodeng.2008.11.017

Chee CP, Djordjevic D, Faraji H, Decker EA, Hollender R, McClements DJ, Peterson DG. 2007. Sensory properties of vanilla and strawberry flavored ice cream supplemented with omega-3 fatty acids. Milchwissenschaft, 62: 66-69.

Chee CP, Gallaher JJ, Djordjevic D, Faraji H, McClements DJ, Decker EA, Hollender R, Peterson DG, Roberts RF, Coupland JN. 2005. Chemical and sensory analysis of strawberry flavoured yogurt supplemented with an algae oil emulsion. J Dairy Res, 72: 311-316. DOI: 10.1017/S0022029905001068

Choi SJ, Decker EA, McClements DJ. 2009. Impact of iron encapsulation within the interior aqueous phase of water-in-oilin-water emulsions on lipid oxidation. Food Chem, 116: 271-
276. DOI: 10.1016/j.foodchem.2009.02.045

Cofrades S, Antoniou I, Solas MT, Herrero AM, JiménezColmenero F. 2013. Preparation and impact of multiple (waterin-oil-in-water) emulsions in meat systems. Food Chem, 141: 338-346. DOI: 10.1016/j.foodchem.2013.02.097

Dalgleish DG. 2004. Food emulsions: their structures and properties. In: Friberg SE, Larsson K, Sjöblom J. Food Emulsions. $4^{\text {th }}$ Edition. New York: Marcel Dekker. pp: 1-44

Dalgleish DG. 2006. Food emulsions- their structures and structureforming properties. Food Hydrocoll, 20: 415-422. DOI: 10.1016/j.foodhyd.2005.10.009

Dalgleish DG, West SJ, Hallett FR. 1997. The characterization of small emulsion droplets made from milk proteins and triglyceride oil. Colloids and Surfaces A: Physicochemical and Engineering Aspects, 123: 145-53. DOI:10.1016/S09277757(97)03783-7

de Cindio B, Grasso G, Cacace D. 1991. Water-in-oil-in-water double emulsions for food applications: yield analysis and rheological properties. Food Hydrocoll, 4: 339-353. DOI:10.1016/S0268-005X(09)80130-6

Delgado-Pando G, Cofrades S, Ruiz-Capillas C, Solas MT, Jiménez-Colmenero F. 2010. Healthier lipid combination oil-inwater emulsions prepared with various protein systems: an approach for development of functional meat products. Eur $\mathbf{J}$ Lipid Sci Technol, 112: 791-801. DOI: 10.1002/ejlt.200900234

Dickinson E. 1992. An introduction to food colloids. Oxford: Oxford Univ. Press. ISBN: 0198552246, 9780198552246

Dickinson E, Stainsby G. 1982. Colloids in foods. London: Elsevier Applied Science Publishers. ISBN: 0853341532

Dickinson E. 2009. Hydrocolloids as emulsifiers and emulsion stabilizers. Food Hydrocoll, 23: 1473-1482. DOI: 10.1016/j.foodhyd.2008.08.005

Dickinson E. 2011. Double emulsions stabilized by food biopolymers. Food Biophysics, 6: 1-11. DOI: 10.1007/s11483010-9188-6

El-Aasser MS, Sudol ED. 2004. Miniemulsions: overview of research and applications. Journal of Coatings Technology and Research, 1: 21-31.

Evison J, Dickinson E, Owusu Apenten RK, Williams A. 1995. Formulation and properties of protein-stabilized W/O/W multiple emulsion. In: Dickinson E, Lorient D. Food Macromolecules and Colloids. Cambridge: Royal Society of Chemistry. pp: 235-243. ISBN: 978-0-85404-700-0

Fanun M. 2009. Properties of microemulsions with sugar surfactants and peppermint oil. Colloid Polymer Science, 287: 899-910. DOI: $10.1007 / \mathrm{s} 00396-009-2043-y$

Fechner A, Knoth A, Scherze I, Muschiolik G. 2007. Stability and release properties of double-emulsions stabilised by caseinatedextran conjugates. Food Hydrocoll, 21: 943-952. DOI: 10.1016/j.foodhyd.2006.10.021

Flanagan J, Singh H. 2006. Microemulsions: a potential delivery systems for bioactives in food. Crit Rev Food Sci Nutr, 46: 221 237. DOI: $10.1080 / 10408690590956710$

Frasch-Melnik S, Spyropoulos F, Norton IT. 2010. $\mathrm{W}_{1} / \mathrm{O} / \mathrm{W}_{2}$ double emulsions stabilised by fat crystals - formulation, stability and salt release. Journal of Colloid and Interface Science, 350: 178185. DOI: $10.1016 /$ j.jcis.2010.06.039

Friberg S, Larsson K 1997. Food emulsions. $3^{\text {th }}$ Edition. New York: Marcel Dekker.

Garti N. 1997. Progress in stabilization and transport phenomena of double emulsions in food applications. Lebensm-Wiss Technol, 30: 222-235. DOI: 10.1006/fstl.1996.0176

Ghosh V, Mukherjee A, Chandrasekaran N. 2013. Ultrasonic emulsification of food-grade nanoemulsion formulation and evaluation of its bactericidal activity. Ultrasonics Sonochemistry, 20: 338-344. DOI: 10.1016/j.ultsonch.2012.08.010

Guraya HS, James C. 2002. Deagglomeration of rice starch-protein aggregates by high pressure homogenization. Starch, 54: 108116. DOI: 10.1002/1521-379X(200204)54:3/4<108::AIDSTAR108>3.0.CO;2-2 
Gutiérrez JM, González C, Maestro A, Solé I, Pey CM, Nolla J. 2008. Nano-emulsions: new applications and optimization of their preparation. Current Opinion in Colloid and Interface Science, 13: 245-251. DOI: 10.1016/j.cocis.2008.01.005

Gülseren İ, Corredig M. 2014. Interactions between polyglycerol polyricinoleate (PGPR) and pectins at the oil-water interface and their influence on the stability of water-in-oil emulsions. Food Hydrocoll, 34: 154-160. DOI: 10.1016/j.foodhyd.2012.11.015

Hemar Y, Cheng LJ, Oliver CM, Sansuansri L, Augustin M. 2010. Encapsulation of resveratrol using water-in-oil-water double emulsions. Food Biophysics, 5: 120-127. DOI: 10.1007/s11483010-9152-5

Iancu MN, Chevalier Y, Popa M, Hamaide T. 2009. Internally gelled W/O and W/O/W double emulsions. e-Polymers, 099. DOI: 10.1515/epoly.2009.9.1.1184

Jafari SM, He Y, Bhandari B. 2006. Nano-emulsion production by sonication and microfluidization- a comparison. International Journal of Food Properties, 9: 475-485. DOI: 10.1080/10942910600596464

Jafari SM, He Y, Bhandari B. 2007. Optimization of nanoemulsions production by microfluidization. Eur Food Res Technol, 225: 773-741. DOI: 10.1007/s00217-006-0476-9

Jiménez-Colmenero F. 2013. Potential applications of multiple emulsions in the development of healthy and functional foods. Food Res Int, 52: 64-74. DOI: 10.1016/j.foodres.2013.02.040

Kanouni M, Rosano HL, Naouli N. 2002. Preparation of a stable double emulsion $\left(\mathrm{W}_{1} / \mathrm{O} / \mathrm{W}_{2}\right)$ : role of the interfacial films on the stability of the system. Advances in Colloid and Interface Science, 99: 229-254. DOI: 10.1016/S0001-8686(02)00079-9

Kara A, Urgu M, Nacak B, Serdaroğlu M. 2013. Effect of water-inolive oil emulsion and carrot powder addition on some emulsion properties of reduced-fat model system meat emulsion systems. In: Serdaroğlu M, Öztürk B, Akcan T. 59 $9^{\text {th }}$ ICOMSTInternational Congress of Meat Science and Technology, 18-23 August, 2013, Izmir, Turkey.

Kentish S, Wooster TJ, Ashokkumar M, Balachandran S, Mawson R, Simons L. 2008. The use of ultrasonics for nanoemulsion preparation. Innovative Food Science and Emerging Technologies, 9: 170-175. DOI: 10.1016/j.ifset.2007.07.005

Kim HJ, Cho YH, Bae EK, Shin TS, Choi SW, Choi KH, Park J. 2005. Development of W/O/W multiple emulsion formulation containing Burkholderia gladioli. J Microbiol Biotechnol, 15: 29-34.

Kim HJ, Decker EA, McClements DJ. 2006. Preparation of multiple emulsions based on thermodynamic incompatibility of heatdenatured whey protein and pectin solutions. Food Hydrocoll, 20: 586-595. DOI: 10.1016/j.foodhyd.2005.06.007

Knoth A, Scherze I, Muschiolik G. 2005. Effect of lipid type on water-in-oil-emulsions stabilized by phosphatidylcholinedepleted lecithin and polyglycerol polyricinoleate. Eur J Lipid Sci Technol, 107: 857-863. DOI: 10.1002/ejlt.200501205

Koberstein-Hajda A, Dickinson E. 1996. Stability of water-in-oil-inwater emulsions containing faba bean proteins. Food Hydrocoll, 10: 251-254. DOI: $10.1016 / \mathrm{s} 0268-005 \times(96) 80042-7$

Krog MJ, Riisom TH, Larsson K. 1983. Applications in the food industry. In: Becker P. Encyclopedia of Emulsion Technology. Vol 2: Applications. New York: Marcel Dekker. pp: 321-365. ISBN-13: 978-0824718770

Krog NJ, Sparso FV. 2004. Food emulsifiers: their chemical and physical properties. In: Friberg SE, Larsson K, Sjöblom J. Food Emulsions. New York: Marcel Dekker. pp: 86-87. ISBN: 978-08247-4696-4

Kwon SS, Nam YS, Lee JS, Ku BS, Han SH, Lee JY, Chang IS. 2002. Preparation and characterization of coenzyme Q10-loaded PMMA nanoparticles by a new emulsification process based on microfluidization. Colloids and Surfaces A: Physicochemical and Engineering Aspects, 210: 95-104. DOI: 10.1016/S09277757(02)00212-1

Laouini A, Fessi H, Charcosset C. 2012. Membrane emulsification: A promising alternative for vitamin $\mathrm{E}$ encapsulation within nano-emulsion. Journal of Membrane Science, 423-424: 85-96. DOI: 10.1016/j.memsci.2012.07.03

Li P, Chiang B. 2012. Process optimization and stability of Dlimonene-in-water nanoemulsions prepared by ultrasonic emulsification using response surface methodology. Ultrasonics Sonochemistry, 19: 192-197. 10.1016/j.ultsonch.2011.05.017

Lobato-Calleros C, Racillas-Mota MT, Espinosa-Solares T, Alvarez-Ramirez J, Vernon-Carter EJ. 2009. Microstructural and rheological properties of low-fat stirred yoghurts made with skim milk and multiple emulsions. Journal of Texture Studies, 40: 657-675. DOI: 10.1111/j.1745-4603.2009.00204.x

Lobato-Calleros C, Rodriguez E, Sandoval-Castilla O, VernonCarter EJ, Alvarez-Ramirez J. 2006. Reduced-fat white fresh cheese-like products obtained from $\mathrm{W}_{1} / \mathrm{O} / \mathrm{W}_{2}$ multiple emulsions: Viscoelastic and high-resolution image analyses. Food Res Int, 39: 678-685. DOI: 10.1016/j.foodres.2006.01.006

Lobato-Calleros C, Sosa-Pérez A, Rodriguez-Tafoya J, SandovalCastilla O, Pérez-Alonso C, Vernon-Carter EJ. 2008. Structural and textural characteristics of reduced-fat cheese-like products from $\mathrm{W}_{1} / \mathrm{O} / \mathrm{W}_{2}$ emulsions and skim milk. LWT-Food Science and Technology, 41: 1847-1856. DOI: 10.1016/j.lwt.2008.01.006

Lutz R, Aserin A, Wicker L, Garti N. 2009. Double emulsions stabilized by a charged complex of modified pectin and whey protein isolate. Colloids and Surfaces B: Biointerfaces, 72: 121127. DOI: 10.1016/j.colsurfb.2009.03.024

Mao L, Xu D, Yang J, Yuan F, Gao Y, Zhao J. 2009. Effects of small and large molecule emulsifiers on the characteristics of $\beta$ carotene nanoemulsions prepared by high pressure homogenization. Food Technol Biotechnol, 47: 336-342. DOI: $10.1080 / 01932690903224482$

Márquez AL, Wagner J. 2010. Rheology of double (W/O/W) emulsions prepared with soybean milk and fortified with calcium. Journal of Texture Studies, 41: 651-671. DOI: $10.1111 / \mathrm{j} .1745-4603.2010 .00247 . x$

Mason T, Wilking J, Meleson K, Chang C, Graves S. 2006. Nanoemulsions: formation, structure, and physical properties. Journal of Physics-Condensed Matter, 18: 635-666. DOI: 10.1088/0953-8984/18/41/R01

McClements DJ, Rao J. 2011. Food-grade nanoemulsions: formulation, fabrication, properties, performance, biological fate, and potential toxicity. Crit Rev Food Sci Nutr, 51: 285330. DOI: $10.1080 / 10408398.2011 .559558$

McClements DJ. 1999. Food emulsions: principles, practice and techniques. London Boca Raton: CRC Press. ISBN: 0849380081

McClements DJ. 2005. Food emulsions: principles, practice and techniques. $2^{\text {th }}$ Edition. London Boca Raton: CRC Press. ISBN: 0849320232

McClements DJ. 2010. Emulsion design to improve the delivery of functional lipophilic components. Annual Review of Food Science and Technology, 1: 241-269. DOI: 10.1146/annurev.food.080708.100722

McClements DJ, Decker EA, Weiss J. 2007. Emulsion-based delivery systems for lipophilic bioactive components. J Food Sci, 72: 109-124. DOI: 10.1111/j.1750-3841.2007.00507.x

McClements DJ, Decker EA, Park Y, Weiss J. 2009. Structural design principles for delivery of bioactive components in nutraceuticals and functional foods. Crit Rev Food Sci Nutr, 49: 577-606. DOI: 10.1080/10408390902841529

Moulik SP, Paul BK. 1998. Structure, dynamics and transport properties of microemulsions. Advances in Colloid and Interface Science, 78: 99-195. DOI: 10.1016/S00018686(98)00063-3

Murillo-Martínez MM, Pedroza-Islas R, Lobato-Calleros C, Martínez-Ferez A, Vernon-Carter EJ. 2011. Designing $\mathrm{W}_{1} / \mathrm{O} / \mathrm{W}_{2}$ double emulsions stabilized by protein-polysaccharide complexes for producing edible films: rheological, mechanical and water vapour properties. Food Hydrocoll, 25: 577-585. DOI: 10.1016/j.foodhyd.2010.06.015 
Muschiolik G. 2007. Multiple emulsions for food use. Current Opinion in Colloid and Interface Science, 12: 213-220. DOI: 10.1016/j.cocis.2007.07.006

Nakajima H, Tomomasa S, Okabe M. 1993. Preparation of nanoemulsions. Proceedings First World Congress on Emulsions, 19-22 October, 1993, Paris, France.

Nakajima H. 1997. Microemulsions in cosmetics. In: Solans C, Kunieda H. Industrial Applications of Microemulsions. New York: Marcel Dekker. pp: 175-197. ISBN: 0-8247-9795

O'Regan J, Mulvihill DM. 2010. Sodium caseinate-maltodextrin conjugate stabilized double emulsions: encapsulation and stability. Food Res Int, 43: 224-231. DOI: 10.1016/j.foodres.2009.09.031

Oza KP, Frank SG. 1989. Multiple emulsions stabilized by colloidal microcrystalline cellulose. J Dispers Sci Technol, 10: 163-185. DOI: $10.1080 / 01932698908943168$

Öztürk B, Serdaroğlu M, Urgu M. 2014. Characteristics of multiple $(\mathrm{W} / \mathrm{O} / \mathrm{W})$ emulsions manufactured with caseinate or egg white powder. $2^{\text {nd }}$ International Congress on Food Technology, 5-7 November, 2014, Kuşadası, Turkey.

Pawlik A, Cox PW, Norton IT. 2010. Food grade duplex emulsions designed and stabilised with different osmotic pressures. Journal of Colloid and Interface Science, 352: 59-67. DOI: 10.1016/j.jcis.2010.08.049

Perrechil FA, Cunha RL. 2012. Development of multiple emulsions based on the repulsive interaction between sodium caseinate and LBG. Food Hydrocoll, 26: 126-134. DOI: 10.1016/j.foodhyd.2011.04.017

Peter GJ. 2009. Encapsulation of flavors in emulsions for beverages. Current Opinion in Colloid and Interface Science, 14: 43-47.

Rao JJ, McClements DJ. 2010. Stabilization of phase inversion temperature nanoemulsions by surfactant displacement. J Agric Food Chem, 58: 7059-7066. DOI: 10.1021/jf100990r

Rao J, McClements DJ. 2011. Food-grade microemulsions, nanoemulsions and emulsions: fabrication from sucrose monopalmitate \& lemon oil. Food Hydrocoll, 25: 1413-1423. DOI: 10.1016/j.foodhyd.2011.02.004

Sanguansri P, Augustin MA. 2006. Nanoscale materials development- a food industry perspective. Trends in Food Science and Technology, 17: 547-556. DOI: 10.1016/j.tifs.2006.04.010

Sapei L, Naqvi MA, Rousseau D. 2012. Stability and release properties of double emulsions for food applications. Food Hydrocoll, 27: 316-323. DOI: 10.1016/j.foodhyd.2011.10.008

Scherze I, Knoth A, Muschiolik G. 2007. Effect of emulsification method on the properties of lecithin- and PGPR-stabilized water-in-oil emulsions. J Dispers Sci Technol, 27: 427-434. DOI: $10.1080 / 01932690500357081$

Seikikawa K, Watanabe M. 2008. Transparent emulsified composition for use in beverages. Givaudan SA, Publication number WO2008/055374.

Serdaroğlu M, Kara A, Öztürk B. 2013a. Multiple emulsions and their applications in food. Proceedings IC FABE 2013- Food and Biosystems Engineering International Conference. 30 May2 June, 2013, Skiathos Island, Greece.

Serdaroğlu M, Öztürk B, Urgu M. 2013b. Utilization of egg white powder and olive oil in turkey meat emulsion systems. Proceedings XXI European Symposium on the Quality of Poultry Meat and XV European Symposium on the Quality of Eggs and Egg Products. 15-19 September, 2013, Bergamo, Italy.

Serdaroğlu M, Öztürk B, Urgu M. 2014. Quality characteristics of meat emulsions manufactured with W/O/W multiple emulsions as fat replacers. $2^{\text {nd }}$ International Congress on Food Technology,
5-7 November, 2014, Kuşadası, Turkey.

Shakeel F, Baboota S, Ahuja A, Ali J, Shafiq S. 2008. Accelerated stability testing of celecoxib nanoemulsion containing cremophor-EL. African Journal of Pharmacy and Pharmacology, 2: 179-183.

Solans C, Solé I. 2012. Nano-emulsions: formation by low-energy methods. Current Opinion in Colloid and Interface Science, 17: 246-254. DOI: 10.1016/j.cocis.2012.07.003

Solans C, Izquierdo P, Nolla J, Azemar N, Garcia-Celma MJ, 2005. Nano-emulsions. Current Opinion in Colloid and Interface Science, 10: 102-110. DOI:10.1016/j.cocis.2005.06.004

Su J. 2008. Formation and stability of food-grade water-in-oil-inwater emulsions. $\mathrm{PhD}$ Dissertation, Massey University, Palmerston North, New Zealand.

Su J, Flanagan J, Singh H. 2008. Improving encapsulation efficiency and stability of water-in-oil-in-water emulsions using a modified gum arabic (Acacia (sen) SUPER GUM ${ }^{\mathrm{TM}}$ ). Food Hydrocoll, 22: 112-120. DOI: 10.1016/j.foodhyd.2007.03.005

Su J, Flanagan J, Hemar Y, Singh H. 2006. Synergistic effects of polyglycerol ester of polyricinoleic acid and sodium caseinate on the stabilisation of water-oil-water emulsions. Food Hydrocoll, 20: 261-268. DOI: 10.1016/j.foodhyd.2004.03.010

Suzuki S, Lim JK. 1994. Microencapsulation with carrageenanlocust bean gum mixture in a multiphase emulsification technique for sustained drug release. J Microencapsul, 11: 197203. DOI: $10.3109 / 02652049409040451$

Swaisgood HE. 1996. Characteristics of milk. In: Fennema GR. Food Chemistry. New York: Marcel Dekker. pp: 841-878.

Swientek RJ. 1990. Microfluidizing technology enhances emulsion stability. Food Processing, 152-153.

Thompson AK, Singh H. 2006. Preparation of liposomes from milk fat globule membrane phospholipids using a microfluidizer. J Dairy Sci, 89: 410-419. DOI: $10.3168 /$ jds.S00220302(06)72105-1

Urgu M, Kara A, Serdaroğlu M. 2013. The effects of using hazelnut oil in water emulsion and hazelnut powder on emulsion properties of reduced fat sausages. Proceedings 59th ICOMSTInternational Congress of Meat Science and Technology, 18-23 August, 2013, Izmir, Turkey.

Vaziri A, Warburton B. 1994. Some preparative variables influencing the properties of $\mathrm{W} / \mathrm{O} / \mathrm{W}$ multiple emulsions. J $\begin{array}{lll}\text { Microencapsul, } & 11(6), & 649-656 .\end{array}$ 10.3109/02652049409051115

Wang X, Jiang Y, Wang Y, Huang M, Ho CT, Huang Q. 2008. Enhancing anti- inflammation activity of curcumin through O/W nanoemulsions. Food Chem, 108: 419-424. DOI: $10.1016 /$ j.foodchem.2007.10.086

Wedzicha BL. 1988. Distribution of low molecular-weight food additives in dispersed systems. In: Dickinson E, Stainsby G. Advances in Food Emulsions and Foams. London: Elsevier Applied Science Publishers. pp: 329-371.

Whitesides GM, Grzybowski B. 2002. Self-assembly at all scales. Science, 295: 2418-2421. DOI: 10.1126/science.1070821

Xia H, Zhang C, Wang Q. 2001. Study on ultrasonic induced encapsulating emulsion polymerization in the presence of nanoparticles. Journal of Applied Polymer Science, 80: 11301139. DOI: 10.1002/app.1196

Xu Y, Liu H, Ma L, Yan Q. 2011. Effect of corn oil $\mathrm{W}_{1} / \mathrm{O} / \mathrm{W}_{2}$ multiple emulsions on quality of low-fat Mozzarella cheese. Proceedings 5th International Conference on Bioinformatics and Biomedical Engineering, iCBBE, 10-12 May 2011, Wuhan, China.

Zhang J. 2011. Novel emulsion-based delivery systems. PhD Dissertation, University of Minnesota, USA. 